\title{
Sprawozdanie z Ogólnopolskiego Zjazdu Historyków Studentów
}

W dniach 30 marca - 2 kwietnia 2006 r. odbył się we Wrocławiu XIV Ogólnopolski Zjazd Historyków Studentów. Jak dotąd była to najliczniejsza tego typu impreza zorganizowana przez studentów Instytutu Historii Uniwersytetu Wrocławskiego. W zjeździe wzięli udział przedstawiciele z 24 ośrodków akademickich $\mathrm{z}$ całego kraju oraz $2 \mathrm{z}$ zagranicy (z Marburga i z Brześcia).

Konferencja rozpoczęła się w czwartek 30 marca o godzinie 17 w Auli Leopoldina w Gmachu Głównym Uniwersytetu Wrocławskiego. Inauguracji dokonał prezes Studenckiego Koła Archiwizacji i Dokumentacji - Łukasz Wolak. Przywitał on studentów oraz poprowadził część oficjalną. Pierwszy wykładu wygłosił prof. dr hab. Rościsław Żerlik, który mówił o historii głupoty, a dokładniej o głupocie osób biorących czynny udział w wielkich wydarzeniach historycznych i o wpływie tych niekoniecznie mądrych decyzji na dzieje losu. Po części oficjalnej nastąpiła ta mniej formalna, która miała miejsce w Piwnicy Świdnickiej - jednym z bardziej znanych we Wrocławiu miejsc, gdzie studenci mieli szanse na zawiązanie nieformalnych znajomości oraz możliwość porozmawiania z uczestnikami, z którymi spotkali się w poprzednich latach. Zmęczenie podróżą spowodowało jednak, że ta część wieczoru zakończyła się raczej szybko.

Piątek, 31 marca, był pierwszym dniem obrad, podczas którego studenci dyskutowali w 13 sekcjach: historii starożytnej, historii średniowiecznej, historii nowożytnej, historii XIX w., Historii Polski do 1945 r. oraz historii powszechnej XX w., historii Polski po 1945 r., historii prawa i ustroju państwa, historii Kościoła i religii do końca średniowiecza, historii Kościoła i religii od końca średniowiecza, historii Niemiec i stosunków polsko-niemieckich, archiwistyki i nauk pomocniczych historii, historii wojen i wojskowości XX w. Sekcje obradowały cały dzień, z jedną przerwą na obiad. W sekcji historii średniowiecza swój referat podparty prezentacją multimedialną wygłosiła Olga Mazurek. Tematem wystąpienia były „Obrzędy i zwyczaje związane $\mathrm{z}$ Narodzeniem dziecka w XIII-XVI w." Do jednych z ciekawszych wystąpień można zaliczyć referaty Anny Wrońskiej z Uniwersytetu Gdańskiego („Cienie i blaski życia trubadura”) oraz Mikołaja Pukianieca (,Misja poselska biskupa Lintpranda na tle stosunku rzymsko-bizantyjskich w pierwszych lata panowania Ottona I"). Wieczorem natomiast zapewniono zwiedzanie miasta $\mathrm{z}$ przewodnikiem, dzięki czemu można było wzbogacić swoją wiedzę na temat Wrocławia.

Sobota była dniem „wycieczkowym”, podczas którego przyjaźnie zawarte na Zjeździe miały szanse się zacieśnić przy okazji poznawania Dolnego Śląska.

W niedzielę do południa miały miejsce jeszcze ostatnie wystąpienia, a także wybór ośrodka akademickiego, który w przyszłym roku będzie organizatorem, już XV, Ogólnopolskiego Zjazdu Historyków Studentów. W związku z szeroko prowadzoną przez Uniwersytet Łódzki akcją promocyjną, wybrano właśnie to miasto na miejsce kolejnego zjazdu.

Mamy nadzieję, że i tam (na kolejnym Zjeździe) będziemy mogli wystąpić ze swoimi referatami, jako pedagodzy $\mathrm{z}$ wykształcenia, a historycy z zamiłowania, reprezentując Studenckie Koło Naukowe Historii Kultury i Edukacji. 